Despite criticisms, however, the paperback edition at its price should be very useful to biology students.

I. T. THREADGOLD

\section{TROPICAL ENCYCLOPAEDIA}

\section{Tropical Crops}

Dicotyledons. By J. W. Purseglove. Vol. 1: Pp. xiv + 1-332. Vol. 2: Pp. viii + 333-719. (Longmans: London, 1968.) 50s. cach volume.

THE appearance of the first two volumes of Professor Purseglove's Tropical Crops is an important event for all concerned with tropical agriculture or with the utilization of its products. In the preface, the author recalls his predicament, as a newly appointed agricultural officer in Uganda some thirty years ago, having to deal with crops which were in many cases totally unfamiliar to him without any general textbook to which to refer for advice. Most of us in the former colonial agricultural services wore at some time or other in similar situations, and, although the past thirty years have seen great developments in tropical agriculture, the situation today is still in many ways difficult. We, and our professional heirs in the developing world, owe Purseglove a great debt for producing a book such as this; he was singularly well fitted for tho task by the breadth of his experience, which coverod East Africa, South-East Asia and the West Indies, and which enabled him to encounter almost every tropical crop plant in life. Of this book it can be said, in all truth, that it "satisfies a long-felt want".

The two volumes of this work available at present cover the dicotyledonous crops. Of these, all those which are of any appreciable significance in the tropical regions of the world are discussed. They are arranged in their natural botanical families, which, with their genera and species, are given in alphabetical order. Under each erop, the essential information available is summarized under logically arranged headings: common names, chromosome numbers, uses, systematics, origin and distribution, cultivars, ecology, structure, pollination, germination, chemical composition, propagation, husbandry, major diseases and pests, improvement and breeding and production and trade. The more important crops (102 in all) are also illustrated with line drawings.

There are those among agriculturalists who appear to care not whence a crop was brought, nor whither its useful products are destined; and their books leave the reader in ignorance on these subjects. Tropical Crops is not such a book. In all the more important cases the origins of the crop, its introduction into cultivation, and its movements about the world are discussed in some detail. It is a pleasant change to see such issues as the ante-European presence of Ipomoea in the Pacific or the global distribution of Gossypium spp. analysed without recourse to the intervention of the mythical beings and improbable voyages invoked by some ethnobotanists. Similarly, the chemical composition data quoted for the crop products, and the discussions of methods of processing and utilization, greatly enhance the value of the book, as do the indications of the magnitude and directions of world trade given.

To condense such an amount of information on such a wide range of crops into some seven hundred pages, even with the extensive use of abbreviations in the text, is a feat in itself: at the same time to present it in a readable form is perhaps an even greater achievement. This book can, indeed, be read with pleasure, and, although its greatest value will probably be as a work of reference, it should also serve well as a source of material for lecturing and for private study.

In preparing an encyclopaedic study such as this, there must be a conflict between the need for treatments sufficiently full to be useful, and the total length (and therefore price) of the book. A happy compromise seems to have been reached here, although some users might willingly pay more for a fuller work, while others might have preferred a smaller, cheaper book, oven if some of the material had to be omitted. I would have liked to see more references included. It is a pity, also, that there are no plates, but the line drawings provide most of the information needed more economically. As it is, the price of five pounds for the two volumes is very reasonable for a work of this scope.

It is hoped that the appearance of the third volume, dealing with monocotyledonous tropical crops, will not be long delayed.

D. G. COURSEY

\section{CHURCH STRETTON GEOLOGY}

Geology of the Country around Church Stretton, Craven Arms, Wenlock Edge and Brown Clee

By D. C. Greig, J. E. Wright, B. A. Hains and G. H. Mitchell. (Explanation of One-inch Geological Sheet 166, New Series.) (Natural Environment Research Council, Institute of Geological Sciences. Memoirs of the Geological Survey of Great Britain, England and Wales.) Pp. xiii $+379+13$ plates. (HMSO: London, 1968.) $30 s$.

THE Church Stretton one-inch geological map (No. 166, published 1967) shows, among much else of interest, the fullest Pre-Cambrian succession in England. The memoir will prove equally valuable to geologists visiting the area for the first time, to university teachers leading vacation excursions, and to research workers.

Church Stretton lies close to the south-eastern "front" of the Caledonian Chain and marks a boundary between very contrasting structural regimes and, arising from this, zones of contrasting sedimcntation. There is only passing reference to this in the memoir. Even though speculative views are involved, it would have been an advantage if the introduction to this, and to other memoirs, had included a sketch map placing the district in the British structural framework.

Most of the chapters deal with successive stratigraphical units; references are given after each chapter, an advantage in a work of this kind. An excellent account is provided of the three divisions of the Pre-Cambrian in the area, the Uriconian, the Stretton Series and the Wentnor Series, and it is clear that full use has been made of modern techniques. Whittard's and James' conclusion that the Longmynd structurally forms a great syncline is on the whole accepted, although it is pointed out that the rightway-up criteria show some anomalios which can perhaps be explained on structural grounds. Sedimentary structures are described, and there are a number of analyses.

Succeeding chapters provide a great deal of information on the stratigraphy, petrography and palaeontology of the Cambrian, Ordovician, Silurian, Old Red Sandstone and Carboniferous; the Silurian includes the famous coralbearing Reef Facies of Wenlock Edge. The analysis of earth movements in the chapter on strueture is stimulating; this scetion contains some references to areas outside the Church Stretton sheet, but might have been even more valuable if such comparisons had been expanded and extended. The Institute of Geological Sciences is now able to eheek stratigraphical and structural conclusions by boring, and five holes have provided uscful information in the Church Stretton area.

The attractions of the Pre-Cambrian and Palaeozoic strata have perhaps prevented some visitors from appreciating the significant glacial geology; this should be rectified by the chapter on the glacial history. A further chapter deals with regional geophysical surveys, and appendices provide lists of fossils.

There is a good selection of ordinary and aerial photo- 